\title{
Oração do Paraninfo á Turma de Bacharelandos de 1938
}

\author{
Pronunciada na solenidade da \\ colação de grau realizada, em 5 de \\ janeiro de 1939, no Teatro Munici- \\ pal de São Paulo.
}

Noé Azevedo

Meus dedicados companheiros de estudo

Durante três anos, sem poesia, sem fantasias, sem ilusões, sem imagens literárias, desdobrámos juntos em nossas aulas os mais graves problemas da vida social e juridica dos nosos dias.

Encarámos a realidade dos fatos soclais e jurídicos despidos do véu artístico com que escritores mais imaginosos costumam envolvê-los, tornando-os menos impressionantes. Mas, apesar da crueza da pintura, nunca perdemos ante os mesmos, a nossa atitude de crítico sempre otimista.

Estamos agora, ao concluir o curso, em face de um dêsses graves problemas. Ao esboçá-lo, de maneira um tanto realista, temo empanar o brilho desta solenidade. Mas estou certo de que, aproveitando a ocasião sobremodo propícia para o apresentar ao estudo e meditação dos competentes, farei obra mais útil do que a de colhêr, nos livros e discursos clássicos, conceitos alevantados e conselhos práticos sôbre o exercício das nobilíssimas profissões ou carreiras de advogado e juiz. 
"Troppi avvocati", é a exclamação que constitue o título do famoso panfleto de Piero Calamandrei.

“Demasiados abogados", é a epígrafe da tradução espanhola.

Mas haverá realmente advogados em demasia?

Estamos aquí diante da maior turma de bacharéis formados pela Faculdade de Direito de S. Paulo. São duzentos e oitenta e quatro os diplomados do ano de 1938.

Constituirá isto um indício de que há advogados em demasia? ou um sinal de que em nosso meio social ainda há lugares para os profissionais das letras juridicas?

Os sábios professores João Arruda e Azevedo Marqes puseram em foco a questão do proletariado intelectual em nosso país, encarando-a, porém, sob prismas diversos e apresentando soluções também dissidentes.

Não resta a menor dúvida que há no Brasil, um grande proletariado intelectual. Não temos o "chômage" operário. Há falta de braços nas indústrias e na lavoura; mas há muitos letrados sem emprêgo, sendo grande a proporção dos necessitados. E o sofrimento dos homens cultos colhidos pela miséria é incomparavelmente maior do que o dos trabalhadores habituados aos rudes serviços braçais.

Em qualquer indústria encontramos centenas de operários percebendo ordenados mensais equivalentes aos dos nossos promotores e delegados de polícia. Aprenderam os ofícios, praticando e ganhando salário compensador, nas próprias fábricas e oficinas, ao passo que os bacharéis em direito tiveram de despender dezenas de contos de réis e uma dúzia de anos porfiados em estudos, nos cursos secundários e superior.

Temos uma legislação abundante creada especialmente pela República Nova, visando a proteção do trabalhador braçal, assim como a dos comerciários, bancários e industriários. Quanto às profissões liberais, entretanto, o novo regime nos deu apenas leis reguladoras do seu exercicio, objetivando mais a sua disciplina do que a proteção ao trabalhador intelectual. 
Em São Paulo, todavia, graças à atuação do dr. Purnio Barreto e à boa vontade da Assembléia Legislativa, pudemos crear, ao lado da Ordem dos Advogados, órgão de disciplina e seleção da classe, uma Caixa de Assistência, que vem prestando moderado auxílio aos colegas em estado de penúria financeira.

Mas não devemos cuidar somente da assistência aos necessitados. Não se resolvem as perturbações da vida social tratando os seus efeitos, curando os males produzidos, pensando as chagas mais dolorosas, mas investigando e descobrindo as causas dêsses distúrbios do metabolismo orgânico social para removê-las, e estabelecer o equilíbrio das funções.

Nâo bastaria, portanto, que os outros Estados seguissem o exemplo de S. Paulo, creando cada qual uma Caixa de Assistência como a nossa, alimentada pelas meias custas contadas aos advogados. Seria uma tristeza que, paraninfando uma turma tão brilhante como esta, désse aos cavaleiros que hoje se armam de entusiasmo e fé para as incruentas lutas do Direito apenas o consôlo de que, nos seus desfalecimentos, teriam o amparo de uma Caixa Beneficente.

Não erram os que assinalam a existência do "chômage" intelectual no Brasil. Esse fenmeno talvez aflija mais a classe dos médicos do que a dos advogados. $\mathrm{E}$ os discípulos de Hipócrates estão sofrendo mais que os de Uipiano justamente por causa do intuito preponderante de assistência, que se nota em toda a legislação trabalhista dêstes últimos decênios.

Grandes pensadores contemporâneos, como Alexis Carrel, Will Durant e Oloff Kinbera, mostram que o desenvolvimento da assistência, no Estado moderno, tem concorrido para uma seleção em sentido inverso, ou regressiva, sacrificando os elementos bons, que ficam ao desamparo, enquanto são beneficiados os elementos fracos, que passam a preponderar no corpo social.

Uma caixa de assistência, com meia dúzia de médicos, em cuja escolha predomina mais a proteção do que a investigação da competência, acode a centenas de trabalhadores. 
Enquanto êsses poucos médicos, estipendiados pelas caixas, trā̄alham demais, não podendo ministrar aos enfermos cuidados mais desvelados que os de rápidas visitas e curativos apressados, ficam centenas de profissionais com os seus consultórios desertos, descrentes da carreira, sem recursos e sem entusiasmo para prosseguirem nos estudos científicos, sem casos para observarmos práticas e para comunicações às academias de Medicina, deixando a ciência de progredir nas investigações e descobertas.

Embora em menor escala, a assistência, tão do agrado dos novos legisladores, vai prejudicando também a classe dos advogados e a dos serventuários da Justiça.

A concessão da assistência judiciária baseia-se na prova de uma negativa, isto é, a da inexistência de recursos da parte de quem impetra o benefício. A prova da negativa, nos casos possíveis, é dificílima, e quasi sempre incompleta.

Contentam-se, por isso, os magistrados com simples atestados de miserabilidade, passados por autoridades policiais ou juízes de paz, para fundamentar a concessão do benefício, que, segundo as regras gerais de direito, deve antes ser ampliado que restringido.

$\mathrm{E}$, assim, vemos que foram, durante o ano findo, atendidos 345 pedidos de assistência judiciária pelos juízes, sendo indicados 351 patronos gratuitos pela presidência da Ordem dos Advogados, na comarca da Capital.

Não é, entretanto, desta assistência judiciária aos necessitados, serviço que de bom grado juramos prestar e alegremente prestamos, que nos advêm profundos cortes nos proventos da profissão. Mas é daquele espírito de assistência aos fracos que caracteriza a transformação do direito contemporâneo, segundo as sábias observações de RIPERT e JosSERAND.

Quem é o fraco nas relações jurídicas?

Fraco é o operário em relação ao patrão, e por isso tem assistência jurídica inteiramente gratis dispensada diretamente pelo Estado. 
Fraco é o devedor em relação ao credor, assim como fraco é o inquilino em face do proprietário; por isso, predominando a política de assistência, como lema de govêrno, que tem de se apoiar na massa popular, formada pelos fracos, mas que tem a fortaleza política do número, concedemes favores e garantias aos devedores e aos inquilinos, contra os capitalistas e os proprietários.

Aparecem, assim, as leis de morátoria e de reajustamento econômico, que impedem a cobrança das dívidas; as leis de "luvas" e de inquilnato, que tolhem os despejos e dificultam a exigência dos alugueres.

Fracos são os trabalhadores do campo em relação aos proprietários de latifúndios, e daí a idéia de se concederem lotes de terras devolutas a êsses lavradores.

Devido a essas leis impregnadas do espírito de assistência aos que são tidos como fracos, a advocacia e todo o serviço judiciário se acham em crise em nosso país, acompanhando, aliás, a situação geral de quasi todas as atividades no mundo contemporâneo.

Desde 1933 cessaram as ações de cobrança e as execuções contra fazendeiros. E como vivemos num país essencialmente agrícola, é bem de ver que se estancou uma das melhores fontes de receita para os advogados e de serviço para a Justiça.

Desde 1933 também, cessaram ou diminuíram extraordinariamente as questões de terras, diante de um decreto que declarou não estarem sujeitos a usucapião os bens públicos, qualquer que seja a sua natureza.

Todas as disputas entre particulares, que, com títulos mais ou menos antigos, demandavam sôbre o domínio e posse de terras devolutas ocupadas há mais de 10,20 ou 30 anos, cessaram diante dêsse verdadeiro "ukase", dado como interpretativo do Código Civil, para ser aplicado retroativamente desde a vigência dêste, que data de 1917.

Em lugar de centenas de advogados ocupados nessas questões, ficou somente a Procuradoria de Terras no Estado 
de São Paulo, com poderes verdadeiramente ditatoriais, com a faculdade até de invocar o auxílio da fôrça pública para despejar trabalhadores que, bem ou mal aconselhados, inverteram na aquisição de títulos dominiais toda a sua economia, e derramaram na terra o suor de toda a família, tantas vezes dolorosamente golpeada pelas enfermidades das zonas maleitosas e pela hostilidade da flora e fauna dos sertões agrestes.

E a experiência histórica aí está a nos mostrar que, sem o pretêxto da defesa de um título, seja êle bom ou mau, não se dominam nem povoam êstes imensos Brasís.

Não fosse propósito de alargar pelo "uti possidetis", a célebre linha de Tordesilhas, e não se teriam feito as entradas épicas pelo sertão, plantando fortalezas nas cabeceiras e nas barras dos grandes rios do continente e disseminando por toda parte os núcleos de povoação, que tanto dilataram os horizontes da Pátria.

Os que entram pelo sertão munidos de um título, cuja melhor defesa está na efetiva ocupação, envidam todos os esforços para atrair compradores e agregados, fazendo da terra virgem brotar cidades, com uma pujança ou vitalidade que surpreende e maravilha.

Os que entram com títulos garantidos do Estado fazem como os donatários das antigas capitanias: deixam, á espera de valorização, as concessões ao abandono, com exceção de um ou outro imitador de Martim Afonso.

Diminuindo extraordinariamente os prélios judiciais por causa dessas leis orientadas pela idéia de proteção aos chamados "fracos", também diminuíram os serviços de escritório: as consultas, a redação de escrituras e contratos de toda espécie.

A falta de crédito dos lavradores, decorrente de tais leis, que os deixaram em condições de perene insolvabilidade, e a redução compulsória dos juros levaram os capitalistas a aplicar suas economias na aquisição de títulos da dívida pública, que continuaram sempre muito bem cotados nas 
Bolsas, apesar da emissão a jato contínuo de formidáveis empréstimos.

Por outro lado, os grandes encargos, impostos às indústrias e ao comércio pela legislação trabalhista e fiscal, diminuíram a organização de emprêsas e constituição de sociedades, atos em que sempre intervinham advogados e empreendimentos férteis em questões forenses.

O melhor e mais convidativo emprêgo de capital passou a ser, indiscutivelmente, o de títulos da dívida pública, negócio outrora reservado aos órfãos, viúvas e velhos aposentados.

$$
\text { * * * }
$$

Eis ai as causas novas da crise por que passa a nossa profissão.

Mas existem também as causas antigas, os males originários, os defeitos orgânicos, que sempre atraíram a grande hostilidade do público contra toda a gente do fôro, considerada como classe parasitária.

Não sendo possível entrar em minúcias, desinteressantes para a maior parte dos ouvintes, direi que o ogeriza votada aos servidores da Justiça provém de duas razões fundamentais: a demora na conclusão dos feitos e o custo excessivo dêsse serviço, que é o primordial do Estado juridicamente organizado.

Lembrei-me, por isso, de aproveitar a solenidade de hoje para impetrar dos poderes competentes medidas capazes de remover êsses dois males antigos, medidas que, postas em prática, seriam suficientes para redimir aqueles outros pecadilhos do novo regime.

As antigas assembléias legislativas, como observou RIPERT, não conseguiam votar leis que obedecessem a um plano pre-estabelecido e de interesse geral porquê, no seio das mesmas, estavam representados grupos com interesses dissidentes, que obstruíam a discussão ou mutilavam os sis- 
temas ideados por grandes técnicos e patrocinados por estadistas de visão mais dilatada.

Hoje, em face do desprestígio e supressão dos parlamentos, dirigem-se as diferentes classes sociais ao govêrno, por meio de comissões e representantes mais ou menos autorizados, e obtêm decretos estabelecendo medidas transitórias ou reformas permanentes, atendendo ao clamor dos aflitos ou à justiça das grandes causas, que se impõem pela fortaleza das próprias razões aos poderes hoje concentrados nessa expressão "govêrno"

Sendo, porém, as pretensões ateñdidas por partes, não se verifica aquele choque de interesses que, nos congressos legislativos, inutilizava os melhores esforços, paralizando os grandes projetos, quebrando a harmonia dos sistemas e produzindo, em geral, obras retorcidas e mirradas, marcadas, em cada capitulo, pela influência dêste ou daquele grupo parlamentar.

Por isso, é natural que as concessões feitas à lavoura, ao operariado, aos comerciários, aos inquilinos, aos funcionários, aos militares e a outras classes e grupos sociais, venham atingir e prejudicar interesses de outras classes, como aconteceu com a nossa.

Não censuramos o Govêrno por haver atendido aos justos ou prementes reclamos dos outros. Mas queremos que também dê atenção ao que vimos pleitear, consubstanciando velhas aspirações de toda a classe dos juristas, e que vem a ser - Justiça rápida e menos dispendiosa.

A razão primordial da existência do Estado é a atuação do Direito.

A escola clássica de Direito Público sustentava mesmo ser essa a sua finalidade única. A escola de Orlando e CavagNari deu grande desenvolvimento à parte da atividade social. E as teorias hodiernas alargaram ainda mais o campo de atuação direta dos poderes do Estado.

Mas, apesar de toda essa evolução, ainda se pode dizer que o fim primordial do Estado é a realização do Direito. 
E essa realização se faz pela distribuição da justiça ou pelo receio das sanções dessa mesma justiça.

E' para realização dos seus fins sociais e políticos que o Estado lança impostos. Os tributos só se legitimam pela necessidade dos mesmos para a consecução das finalidades jurídico-sociais do Estado.

O Estado atua por intermédio de três poderes que se reputavam harmônicos, independentes ou coordenados, e que deveriam ser também equivalentes. Um dêsses poderes é o Judiciário.

Examinando-se o orçamento do Estado de S. Paulo para o exercício de 1939, que acaba de ser publicado com o decreto n. 9.870, de 27 de dezembro p. passado, vê-se que a despesa geral efeitiva é de 906.239:277\$210. A despesa total com o Poder Judiciário e o Ministério Público, compreendendo, portanto, todo o serviço de Justiça prestado pelo Estado, inclusive material e manutenção do Palácio da Justiça e foruns do interior, atinge apenas a $13.606: 216 \$ 800$.

Deduzindo-se a verba de custas e emolumentos de 5.600:000\$000 constante da receita, fica o dispêndio reduzido a $8.006: 216 \$ 800$, a menos, portanto, de $1 \%$ da despesa geral efetiva.

Seria, portanto, uma insignificância, uma ridicularia, uma coisa verdadeiramente irrisória, o que o Estado estaria assim despendendo para realização da sua finalidade primordial.

Mas nem isso realmente êle despende. $E$ hão de ficar assombrados ao constatar que o Estado talvez faça mercancia com a Justiça, auferindo provavelmente lucros por intermédio dêsse departamento da administração pública.

Basta atentar para a circunstância de que figura na receita a verba de 32.000:000\$000 proveniente do imposto de sêlo sôbre atos emanados dos poderes do Estado, e ponderar-se que grande parte de tais selos é aplicada nas folhas 
dos processos forenses, para se ver que, bem feitas as contas, o serviço da Justiça sai de graça, se não deixar bom rendimento.

Penso não errar, quer do ponto de vista jurídico, quer encarando o assunto pelo prisma da moral, afirmando que o serviço de distribuição da Justiça e de atuação do Direito na sociedade, missão precípua do Estado, não pode ser erigido em emprêsa lucrativa, devendo ser custeado pela renda dos impostos gerais.

Assim, nada mais justo do que contemplar-se o Poder Judiciário com uma verba menos usurária, num orçamento de um milhão de contos.

Se o serviço não rende, se os processos não andam, se a Justiça é desesperadoramente demorada, isso naturalmente provém da falta não direi de braços, mas de cérebros postos ao seu serviço.

Aumenta-se a produção industrial ampliando-se o maquinário e o quadro do pessoal. 0 aparelhamento da Justiça é quasi que exclusivamente pessoal, pois nem mesmo o gênio inventivo dos americanos do norte conseguiu mecanizá-lo.

Nomeiem-se, portanto, mais juízes, faça-se melhor distribuição das causas, e, fatalmente, se há de aumentar e melhorar a produção, produzindo-se, se não aceleradamente, pelo menos com uma rapidez compatível com a aceleração da vida contemporânea.

De acôrdo com o decreto $\mathbf{n}$. 9.775, de 30 de novembro do ano p. pasasdo, que fixou o novo quadro da divisão territorial do Estado, temos 126 comarcas e termos, 270 municípios e 588 distritos.

$\mathrm{O}$ ideal seria que todas as autoridades judiciárias soubessem Direito e que todos os juizes de paz dos 588 distritos fossem diplomados, para que, ao menos, prevalecesse a presunção, nem sempre correspondente à verdade, de que são versados em Direito. 
Não sendo possivel atingir a essa perfeição técnica, já considerariamos grande avanço nomear-se um juiz municipal para cada um dos 270 municípios. $\mathrm{E}$ se isto ainda parecer muito arrôjo aos chanceleres do erário, que então se nomeie pelo menos um juiz para cada termo nas comarcas de primeira, segunda e terceira entrâncias, e maior número nas comarcas de entrâncias superiores.

Só assim a expressão “termo", usada na divisão territorial, poderá ter uma significação, de acôrdo com o decretolei n. 311, de 2 de março de 1938, segundo o qual o termo vem a ser uma circunscrição judiciária,"falando-se expressamente em "termo judiciário"

De outra maneira, como está no decreto estadual, o termo se confunde com a comarca.

E para desemperrar o serviço da Justiça é indispensável que haja um juiz togado abaixo do Juizo de Direito, afim de julgar as pequenas causas de valor até 5:000\$000 ou 10:000\$000, com recurso para aquele Juízo, pois só assim se aliviará da avalanche de autos o Tribunal de Apelação, órgão evidentemente hipertrofiado pela sobrecarga de trabalho e pela aglomeração de julgadores.

Mas não bastará a creação dos juizes de termo e a supressão de recurso para o Tribunal, em causas de pequeno valor, para equilibrar o serviço. Ficaremos com juízes suficientes no interior do Estado, mas com juízes de menos na Capital, onde a situação é de verdadeira penúria.

O serviço forense da Capital é maior que o do resto do Estado, tanto assim que aquí estão inscritos, na sub-secção da Ordem dos Advogados, mais de 2.100 profissionais, ao passo que, em todas as sub-secções do interior, contam-se apenas 1.300 .

Entretanto, existem na Capital somente 46 magistrados, inclusive o juiz preparador do Juri, sendo 21 juizes de primeira instância e 25 desembargadores do Tribunal de Apelação, para atenderem ao trabalho de um número de advogados correspondente quasi ao dôbro dos profissionais do 
interior, que atualmente já contam com 130 juizes de direito e 24 substitutos.

Precisamos, conseguintemente, de aumentar, mas aumentar sem parcimônia, sem mesquinharia, sem visar o reembôlso por via de custas e emolumentos, aumentar com larga visão de assinalados benefícios e proventos de ordem geral, - precisamos urgentemente aumentar o número de juízes da cidadie de São Paulo, creando juízes de termo para julgarem as causas de pequeno valor, e magistrados de largo tirocínio para comporem os juízos coletivos ou câmaras de primeira instância, que permitam a introdução da oralidade em nosso procedimento, sem a qual não se conseguirá o "desideratum" da rapidez nos julgamentos.

$$
\text { * * * }
$$

Ruy Barbosa, na platatorma de 1910 lida na Baia, já assinalara nestas palavras lapidares as vantagens do processo oral:

“Alguns traços o definem: simplificação, rapidez, segurança, barateza, honestidade. Adverso à chicana, favorável ao desenvolvimento das capacidades na advocacia e na magistratura, satisfatório na garantia dos interesses dos pretendentes, acredito que a sua inauguração, reanimando a confiança na Justiça, restituiria a vida ao Fôro, habituando o Direito a resistir, em vez de se entregar por descrente dos Tribunais e desanimado com os vexames do seu processo"

Desde o notável trabalho apresentado pelo professor Francisco Morato ao Congresso Judiciário de 1936, vêm os juristas brasileiros meditando sôbre o assunto e se convencendo de que a verdade está com êsses grandes mestres, que a foram colhêr nas lições de Chrovenda, o grande sistematizador dos estudos de processo, aquele que, segundo o mesmo Ruy, imprimiu ao Direito Judiciário os caracteristicos de lídima ciência. 
A "Revista Forense", consultando a opinião dos mais abalisados juristas do pais, colheu uma série de artigos notáveis, sustentando decididamente a tese da oralidade. formando sôbre o assunto uma preciosa monografia, que enche quasi todo o fascículo de maio do ano próximo passado.

O mundo todo vem reformando as suas leis processuais, seguindo a orientação do processo germânico, predominantemente oral.

Em São Paulo, a Ordem dos Advogados, há cêrca de dois anos, opinou pela sustentação oral dos recursos; e o Instituto dos Advogados se pronunciou, há poucos meses, pela prevalência da oralidade no procedimento.

Mais eloquentes, porém, do que todos êsses argumentos são os dados estonteantes das estatisticas austríacas, quanto à celeridade advinda do procedimento oral, as quais, segundo Chrovenda, assinalavam o seguinte resultado: $45 \%$ das causas ordinárias do Tribunal foram decididas em um mês, contado do seu ínicio; $35 \%$ em três meses; $15 \%$ em seis meses; apenas $5 \%$ em um periodo excedente de seis meses, e, dentre essas, só uma causa sôbre cem em um periodo excedente a um ano ("Revista Forense", vol. 74, pág. 182).

Mas, como demonstra o professor José Augusto Garcia na introdução ao seu projeto de reforma da legislação processual argentina, o procedimento oral pressupõe juizos colegiais de primeira instância, para que se possa dar a concentração da causa, pondo-se os juizes, que têm de julgar os fatos contorvertidos, em contacto imediato com as partes, com as testemunhas, peritos e demais meios produtores da certeza.

Somente serão interpostos recursos sôbre matéria de direito, ficando os fatos definitivamente acertados pelo juízo de primeira inståncia. E para que êsse julgamento definitivo sôbre os fatos satisfaça os anseios de justiça dos litigantes, que jamais se contentarão com a sentença de um juiz único, é indispensável a instituição de câmaras ou juízos colegiados. 
$\mathrm{Na}$ Capital, dada a circunstância de serem evidente mente insuficientes os vinte juizes destinados a fazer face a dois mil e muitos advogados, deve-se transformar cada uma das vinte varas em câmaras de três juizes, elevando-se assim o número dêstes para sessenta.

Nas comarcas onde, devido ao grande movimento forense, já temos mais de uma vara, a cada uma destas serão agregados mais dois juizes. As demais comarcas serão agrupadas de três em três, observada a maior facilidade de comunicação, reunindo-se os três juizes uma vez por semana em cada uma dessas mesmas comarcas, para o julgamento das causas ai ajuizadas.

Assim teremos um Poder Judiciário eficiente, satisfazendo as exigências do nosso desenvolvimento econômico e intelectual, e dignificaremos toda a classe dos juristas, que passará a prestar reais serviços à sociedade, deixando a gente do fôro de constituir um espantalho para todos os que encontram dificuldades na solução de seus negócios, preferindo sacrificar boa parte da sua fazenda, para não perder tudo querendo fazer valer os seus direitos perante os tribunais.

Conta Calamandrei que um pintor mordaz, graças à dedicação de um advogado, moderado, aliás, em seus honorários, conseguiu ganhar uma pequena demanda, depois de infanda e tormentosa discussão.

Em sinal de gratidão, pintou com esmêro e arte um dos seus melhores quadros, enviando-o de presente ao esforçado patrono. O quadro trazia esta legenda: "O cliente que ganhou a demanda"; mas na tela o que aparecia era... um frango depenado!.

Assim, acredito, com Ruy Barbosa, que a inauguração do processo oral, "reanimando a confiança na Justiça, restituiria a viảa ao Fôro, habituando o Direito a resistir em vez de se entregar por descrente dos Tribunais e desanimado dos vexames do seu processo" 
Sim. Restituiria a vida porquê povoariamos o fôro de maior número de juízes e de advogados, assim como de copiosas demandas. Hoje podemos dizer que o maior benefício prestado pela Justiça está justamente na demora da terminação dos feitos e nos resultados verdadeiramente ruinosos das disputas judiciais. Apavoradas com a visão de tais consequências, as partes se acomodam sem ir ao Fôro. E quando a exaltação de ânimos seja tão grande que impeça o entendimento, levando-se a contenda ao pretório, enquanto esta se protela e eterniza, os ânimos arrefecem, evitando-se a luta direta, a violência dos pugilatos, a consternação das grandes tragédias. É a ação negativa da Justiça, a produzir, excepcional e paradoxalmente, algum benefício.

Antigamente, chamavam-se "oratores" os advogados. No São Paulo de nossos dias, de processo pode-se dizer que integralmente escrito, os advogados não falam. Os oradores se transformaram em escribas. Só há oportunidade de falarem perante o juri, no julgamento dos poucos crimes que ainda compete ao tribunal popular, e perante as câmaras criminais, nos raríssimos casos de "habeas corpus"

Entendo também, com Ruy Barbosa, que a oralidade é favorável ao desenvolvimento das capacidades na advocacia e na magistratura. Ela propiciará, por sem dúvida, o desenvolvimento cultural dos postulantes e julgadores, e dará às partes a segurança de que os argumentos em prol de seu direito foram ouvidos e apreciados pelos distribuidores da justiça.

Não queremos restabelecer a velha e pomposa oratória, cheia de som e vasia de substância. Na realidade, como diz Calamandrei, a desejada introdução da oralidade no processo civil não significará a abertura de suas portas à grande oratória, pois que oralidade, segundo a concebemos, equivalerá a diálogo quotidiano entre advogado e juiz, compreensão recíproca, alimentada pelo conversar sem o alçar da voz. "O juiz que ouve embevecido o grande orador admi- 
ra-o tanto que o sente Ionge de si; mas entre juiz e advogado não há de ocorrer admiração, e sim confidência, comunhão de idéias: sentirem-se servidores do mesmo dever, membros da mesma família".

Nota êsse escritor que quando, no trato quotidiano da vida, algumas pessoas querem se entender a respeito de um assunto, reúnem-se e trocam idéias, dialogando, e esclarecendo-se mutuamente. Seria espantoso que engenheiros civís, arquitetos e capitalistas, para assentarem os planos e orçamentos de uma grande construção, se reunissem num salão imenso, diante de uma assistência multifária, e se pusessem a discursar em linguagem altissonante, com todas as figuras de retórica, sôbre a resistência dos materiais, sôbre os estilos arquitetônicos e sôbre as doutrinas econômicas que pudessem ter qualquer atinência com a aplicação do capital em construções.

Observa Henri Robert que nas assembléias legislativas são os advogados os que menos falam, sendo os menos palavrosos e prolixos quando têm de falar. "Car l'avocat a été soumis professionnelement à une discipline de la pensée, à une règle oratoire qui lui permettent d'être, plus que n'importe qui, toujours maître de sa parole"

“A parolagem, a prolixidade, as inutilidades são próprias de oradores desprovidos de experiência e método, que falam sem nada dizer, que não vêem claramente aonde vão, nem tão pouco onde devem parar. Para tratar de uma questão com clareza, concisão e nitidez, não há como o hábito da argumentação forense, baseada no estudo das causas, creando um grande poder de penetração e de apreensão rápida dos mais complexos problemas, pondo logo em plena luz o seu ponto capital” (“L'Avocat”, pág. 97).

"A eloquência - diz outro ilustre "bâtonnier" francês - não é somente uma arte, mas a mais difícil de todas as artes. Eloquente não é aquele que expõe claramente uma longa série de fatos e sabe classificá-los ou encadeá-los. Não é o que descreve com traços pitorescos e vivos, nem o que 
esclarece as obscuridades, dissipa os equívocos e tira de uma idéia todas as suas consequências. $E$ ainda não é aquele que, numa gradação ritmada e harmoniosa de frases habilmente cadenciadas, agrada o ouvido, excita a imaginação e toca o próprio coração. Mas é aquele que reúne todos e tão excelsos predicados, possuindo, ao mesmo tempo, a arte de contar, a arte de pintar, a arte de provar, a arte de agradar e comover" (Fernand Payen, Le Barreau", pág. 221).

O que mais temem os adversários da oralidade em nosso país é a verbosidade da nossa gente. Mas nada melhor para combater o verbalismo ôco do que a disciplina da discussão forense. "Soyez en garde, vous tous qui avez reçu du Ciel le dangereux présent de la facilité. Ne croyez pas aux brillantes et victorieuses improvisations. La semence de Vulcain répandue au hasard sur le Monde n'a produit que des monstres” (Fernand Payen, op. cit., pág. 274).

Thiers, Berryer e Emile Olivier, tidos como dos maiores improvisadores de França, confessaram, entretanto, que o segrêdo de seus triúnfos estava justamente na circunstância de que nunca improvisavam. Estudavam pacientemente os assuntos, meditavam longamente sôbre os mesmos e concatenavam metodicamente tudo quanto deviam dizer. A arte de bem falar, o encanto e a fôrça da oratória forense. ensina Fernand Payen, se reduzem ao seguinte lema: Não ler, não recitar, nem improvisar.

Mas como poderemos conseguir que juízes e advogados não improvisem, se pretendemos estabelecer o processo oral e êste reclama que o julgamento se faça, em regra, na mesma audiência em que as partes discutem, e se colhem os principais elementos probatórios?

Os advogados evitarão o improviso levando todas as suas alegações bem estudadas quanto aos fatos, e revendo cuidadosamente os pontos de doutrina que tenham ligação com a matéria.

Aos juízes pouparemos o esfôrço da improvisação, preparando-os para falar de cátedra sôbre todas as questões que 
constituem a especialização das câmaras em que pontificam. Em vez de passarem as noites e as manhãs entregues ao trabalho estéril de ler escrituras públicas, depoimentos de testemunhas, autos e certidões de oficiais de justiça, laudos periciais sôbre divisas de terras, contas de comerciantes, etc., aplicarão essas horas de lazer na leitura de bons livros e revistas de direito.

Assim, a discussão oral séria e disciplinada entre advogados e juizes constrangerá todos a aperfeiçoarem os seus estudos de direito e também de humanidades. Não haverá incentivo algum mais poderoso para o desenvoivimento cultural de magistrados e causídicos do que o desejo de fazerem boa figura nos diálogos que se hão de travar nas audiências públicas. Foi por isso que o gênio de RuY BarBOSA já apontara como primeira das vantagens grangeadas pela oralidade o favorecer o desenvolvimento das capacidades na advocacia e na magistratura.

Dizem os adeptos do processo escrito que êste favorece mais o desenvolvimento da literatura jurídica, porquê os advogados publicam as suas razões, transformadas, muitas vezes, em substanciosas monografias, e os juízes, escrevendo as sentenças, costumam enriquecer as nossas bibliotecas com opulentos volumes de casos julgados, tornando-se os melhores colaboradores das nossas revistas jurídicas.

Mas é essa tendência dos nossos juristas de só escreverem sôbre casos forenses, que precisamos combater, afim de que a cultura jurídica se eleve, aparecendo obras de sistematização dos diversos ramos do direito, monografias sôbre assuntos de ordem geral, assim como artigos de doutrina desligados do casuísmo forense, proporcionando-nos a leitura de verdadeiras revistas de direito, em vez de massudos repertórios de jurisprudência.

Hoje qualquer advogado pode escrever longas e eruditas razões, conversando com os colegas mais competentes e copiando as citações de autores e julgados nas bibliotecas 
públicas, servindo-se dos longos e sempre dilatáveis prazos que tem para falar nos autos.

Os juízes também, descansando nas contribuições juridicas trazidas pelas razões das partes, podem apresentar sentenças carregadas de fácil erudição.

Mas, para fazerem demonstração de cultura, pleiteando ou decidindo com firmeza, elevação de vistas e precisão de conceitos, necessitam, tanto uns como outros, trazerem não somente a casa, mas o próprio cérebro forrado de escolhida biblioteca.

E não constituirá a oralidade apenas um excelente fator de elevação cultural em nossos meios jurídicos. Ela concorrerá poderosamente para solução daquele angustioso problema que de início nos propusemos estudar — o do "chômage" dos intelectuais, sem desviar as vocações juridicas para o estudo da química ou da eletricidade, como alvitrara o professor João Arruda.

Acabamos de ver que existe serviço de mais para os juizes e de menos para os advogados. Aumentando-se o número de magistrados, aproveitando-se melhor o seu trabalho pela concentração das causas no tempo; não se desperdiçando pelo seu afastamento estudos já feitos e votos já proferidos; não se tendo de, tantas vezes, reiniciar o estudo de causas que já estavam, no Tribunal, com revisão completa, à espera de julgamento; - o procedimento oral, abreviando por mil modos a marcha dos processos, grandemente simplificados, restabelecerá a confiança na Justiça, povoando-se o Fôro de litigantes e de clientes os escritórios dos advogados.

Além disso, proporcionará uma distribuição melhor do serviço. O processo escrito permite o açambarcamento das causas por um pequeno número de grandes advogados. Contando sempre com a gentileza dos colegas "ex adverso", raramente assinam prazos e cobram autos, ficam êstes paralizados muito tempo nos cofres dos causidicos, assoberbados de serviço, à espera de oportunidade para serem arra- 
zoados. E, como observava há dias o dr. Abrahão Ribeiro, é possivel que os processos fiquem abandonados mais tempo nesses escritórios do que nas casas dos juízes e desembargadores. Nem sempre a qualidade do trabalho produzido pelos grandes nomes da advocacia compensará o tempo assim perdido. E sempre essa concentração de causas nas mãos de poucos privilegiados pela inteligência ou pela sorte há de prejudicar os jovens colegas, privados de oportunidade para demonstração de talento e habilidade.

$O$ procedimento oral removerá certamente êsse grande mal. Um advogado sozinho não poderá, no mesmo dia, comparecer perante várias câmaras, para defender diversas causas. Nem lhe será licíto protelar indefinidamente a realização das audiências, porquê os relatores terão efetiva intervenção no andamento dos feitos, competindo-lhes a determinação da ordem dos julgamentos. Os grandes escritórios deixarão de ser unipessoais, precisando o seu chefe de selecionar um corpo de verdadeiros centros de cultura juridica, em tôrno bons auxiliares, dividindo com êles não só o seu trabalho, como também o seu saber, formando-se dos mestres da advocacia.

$$
\text { **** }
$$

Não há necessidade, portanto, de se combater o costume. generalizado em todo o pais, de procurarem as escolas superiores os filhos de fazendeiros, comerciantes, industriais, funcionários públicos e até mesmo de operários, em vez de se dedicarem aos misteres e oficios, considerados mais úteis para a economia geral, desempenhados por seus pais, em condição mais humilde, porém mais produtiva.

Essa tendência constitue um fato social, decorrente das nossas condições mesológicas e demográficas, cuja direção não poderá ser mudada com advertências ou conselhos, por mais sábios e paternais que sejam.

Enquanto houver essa fascinação pela alta cultura, levando pais abnegados a privarem-se, às vezes, do necessário, 
afim de sustentar os filhos nos centros universitários, dando-lhes cartas de doutores em vez de terras, arados, máquinas, martelo ou buril para o trabalho - teremos aí mais uma razão de orgulho que motivo para lástima.

Não terão depois os doutores recursos para viver, nem campo para o exercício das suas profissões. Continuarão, em legiões, a procurar como táboa de salvação o emprêgo público. Penso, todavia, que, assim como na Inglaterra o Estado sustenta milhões de operários desempregados para conservar a posição conquistada no mundo industrial, o Estado aquí no Brasil terá de amparar os diplomados das escolas superiores, tratando de aproveitar a sua atividade, ampliando sempre, com êles, os quadros do funcionalismo público para honrar os seus foros de nação civilizada.

Nas nossas escolas superiores é bem possível que seja deficiente o ensino das ciências, mas nelas domina, de maneira inconfundível, cada vez mais acrisolado, o sentido da nacionalidade, o espirito de brasilidade.

Disse JosÉ Ingenieros que mais do que o ferro, o carvão e o petróleo, concorreu para a grandeza dos Estados Unidos da América do Norte o espírito de americanismo dominante em suas escolas. Foi êsse espírito que absorveu e amalgamou, dando-lhes alma e caráter americanos, aquelas formidáveis correntes imigratórias, fundindo num só povo povos das mais diversas origens e dos mais contraditórios sentimentos.

Somos um país de civilização dativa, em que o aperfeiçoamento cultural das classes dirigentes tem de contrastar com o obscurantismo das massas para que, nas relações internacionais, não sejamos considerados como povo bárbaro, digno de volta à primitiva e humilhante condição de colônia.

São frequentes as lamentações de sociólogos e pensadores nossos vendo o imigrante estrangeiro prosperar economicamente no comércio, na lavoura e nas indústrias, enquanto o brasileiro, dominado pela mania do diploma, 
vive a mendigar lugares nos ministérios e secretarias. Mas êsse fato tantas vezes observado e inutilmente censurado tem, naturalmente, as suas causas profundas em nossa psicologia social. Em vez de procurar essas causas para combatê-las, parece que nos devemos felicitar pela existência dêsse fenômeno, mercê do qual poderá toda a administração pública do Brasil, em todas as suas formas de atividade, ser dirigida e orientada por brasileiros, mantendo-se a cultura brasileira sempre em nivel superior à da massa imigratória e em pé de igualdade com a dos povos que se julgam supercivilizados.

Sendo o Brasil um país novo, em que surgem a todo momento problemas novos nas relações jurídicas em todos os quadrantes da atividade econômico-social, precisamos de homens cultos para resolver tais dificuldades e, especialmente, de juristas, cujos cérebros constituem verdadeiras antenas, sensíveis às ondulações provenientes dos mais diversos setores da comunidade, e que tratam de evitar os choques, de impedir a confusão, separando e selecionando os fatos, movimentos ou aspirações, subordinando tudo ao ordenamento geral do direito, produtor da sincronização e harmonia.

Disse o ministro Francisco Campos, eminente professor de Filosofia do Direito, que "os legistas são, por natureza, conservadores, e a perspectiva de mudanças, inovações ou experiências sempre os intimida. Os interesses creados constituem o centro das suas preocupações. Nos arranjos ou nas combinações dos mecanismos de govêrno, de processo ou de Justiça, o que domina o seu espírito não é o lado dinâmico, liberal ou progressista, mas o estático, o das garantias que assegurem a permanência do statu quo, a duração do adquirido, a estabilidade das situações consolidadas, a conservação dos interesses creados ("Revista Forense", vol. 73, pág. 274)"

De nada precisamos mais no Brasil do que de ordem e estabilidade. Revoluções já temos tido em demasia. E isso 
porquê o espirito de conservação dos bacharéis nem sempre conseguiu refrear os impulsos da mentalidade simplificadora de outras classes ou grupos sociais.

Não pōdemos entretanto, permanecer encantonados pela muralha chinesa das velhas fórmulas juridicas. É preciso que o mundo dos legistas não seja exclusivamente o dos arquetipos ou das fórmulas cristalizadas pela experiência do passado, segundo a feliz expressão do eminente estadista. Renovemos as nossas instituições. Mas façamos a renovação sem o aniquilamento de tanto "saber de experiência feito"

Para assegurar a subsistência da nacionalidade, a predominância do espírito brasileiro, formado de sentimentos e concepções que tanto nos elevaram no concêrto das nações civilizadas, para que êsse espírito resista galhardamente aos embates das ondas de sangue e de idéias, impelidas pela convulsão do Velho Mundo, - precisamos manter um alto nivel cultural, em que prepondere o sentido de conservação, sem contrariar, todavia, as exigências da evolução.

Não devemos, portanto, represar a corrente que impele a nossa mocidade para as escolas superiores, nem desviar o curso das vocações individuais, fazendo seriação compulsória de tantos médicos, tantos advogados, tantos engenheiros, tantos veterinários, tantos agrônomos, tantos químicos, tantos eletricistas ou tantos literatos, tudo certo e numerado, porquê êsse trabalho conduziria ao aniquilamento de personalidades fortes, tolhendo o desenvolvimento natural da mentalidade coletiva.

Em nosso país há lugar de sobra para os intelectuais, profissionais de todas as especialidades. $O$ que acontece é que tudo continua desaproveitado. Assim como nós os brasileiros não conseguimos explorar as riquezas naturais do Brasil, o Brasil não sabe tirar partido da inteligência de seus filhos.

Mas esta falange de intelectuais que hoje lhe oferecemos, estou certo, se há de impôr à sua admiração e reco- 
nhecimento, não só pela imponência do número como, principalmente, pela superioridade do talento, pela seriedade dos estudos, pela gravidade de sua formação cultural, desanuviada da fumaça palavrosa de um Direito e de uma Justiça altissonantes, mas bem aprestada de conhecimentos técnicos, imbuída de uma concepção exata dos deveres do cìdadão, recamada de entusiasmo e cheia de fé na profissão que abraçamos, na missão superior e quasi divina de transmudar o embate violento dos interesses e paixões humanas em prélios elegantes, disciplinados e atraentes da inteligência, que, em vez de espalharem a ruína, a morte e a desolação, desabrocham em sentenças finais, expressão de saber e de prudência, representando fórmulas de paz, em termos de concórdia ou conformidade, capazes de estabelecer o ritmo da ordem, prenúncio de harmonia e solidariedade entre os homens. 